\title{
Student Outcomes Associated with Short- term and Semester Study Abroad Programs
}

\author{
Jeffrey Scott Coker \\ Westminster College
}

\section{Evan Heiser Laura Taylor \\ Elon University}

\begin{abstract}
:
This five-year study of graduating seniors at Elon University $(n=1,858)$ compared student outcomes measured by the National Survey of Student Engagement across five study abroad groups: no study abroad, semester, short-term (three-week), two short-terms, and semester plus short-term. Both short-term and semester programs were positively associated with how students rate their overall educational experience and whether they would attend the same institution again. However, students who participated in semester programs reported better outcomes in numerous categories: contributing to class discussion, including diverse perspectives in discussions and assignments, synthesis of ideas, less rote memorization of course material, empathy, acquiring a broad general education, critical thinking, and working effectively with others. There was less compelling evidence of better outcomes from a second short-term program or one taken in addition to a semester program. Overall, short-term programs clearly have value, but semester programs are associated with significantly better outcomes overall.
\end{abstract}

\section{Introduction}

Over $60 \%$ of study abroad experiences are one to eight weeks in duration, a percentage that has grown substantially over several decades (Institute of International Education, 2015). Short-term study abroad programs can lead to meaningful gains in a range of student outcomes (Chieffo \& Griffiths, 2004; Dwyer, 2004; Gaia, 2015; National Survey of Student Engagement, 2007). For example, Dwyer (2004) found that six-week programs offered benefits to important academic, personal, career and intercultural development outcomes that in some areas rivaled semester programs. Likewise, Gaia (2015) used pre- and post-tests to show that three-week programs can enhance "understanding and awareness of other cultures and languages, appreciation of the impact of other cultures on the world, and awareness of their own identity" (p. 21). A study of "transformative learning" (defined as a change in how one understands the world) showed that programs of 19-35 days, 36-49 days, and 50+ days produced similar results, while those of 0-18 days produced worse results (Strange and Gibson, 2017).

However, numerous studies have found that study abroad of longer duration (typically a semester or longer) has more benefits in developing intercultural sensitivity, global perspective, linguistic ability, lifelong friendships with host-country nationals, and many other outcomes (Dwyer, 
2004; Ingraham \& Peterson, 2004; Kehl \& Morris, 2008; Medina-López-Portillo, 2004; Zorn, 1996). For example, Kehl and Morris (2008) found that semester programs increased students' globalmindedness, but found no such evidence for programs of eight weeks or less. A longitudinal study by Dwyer (2004) found that a wide variety of benefits were better sustained through longer study abroad, with yearlong programs showing the greatest gains. Another study found that employers associate low importance with shorter study abroad programs of one to three weeks and much higher importance with longer programs (Trooboff, Vande Berg, \& Rayman, 2008). Gaia (2015) concluded that short-term programs (using an embedded faculty-led model) are an "effective and practical option" (p. 29) for increasing intercultural competency, but "long-term programs remain a particularly valuable academic experience for which short-term programs will never be a substitute" (p. 29).

Engle and Engle (2003) proposed a five-tier system for indicating program quality and depth of immersion, progressing from study tours of a few days to a few weeks (level one) to cross-cultural immersion programs of a semester or year (level five). In a stinging criticism, the president of the Foundation for International Education went so far as to say that short-term programs "blur the distinction between education abroad and educational tourism" and "weaken the credibility of our field," while going on to say that they may be justified when students have no other opportunity (Woolf, 2007).

One multi-institution study came to the conclusion that study abroad duration did not strongly correlate with measures of global engagement (Paige et al., 2009). This study looked at duration of study abroad experiences as a continuum of one-month intervals from one to thirteen. Based on Engle \& Engle's (2003) levels of study abroad, only 10.6\% of students in the study were in what would be considered a short-term program, the one-month or two-month categories, and so the question of differences between short-term study abroad experiences and long-term study abroad experiences is not specifically addressed by the study.

Studies on the effects of program length in other forms of experiential learning show trends similar to the study abroad literature. Longer programs tend to have substantially better outcomes as shown in undergraduate research (Russell, Hancock, \& McCullough, 2007; Zydney, Bennett, Shahid, \& Bauer, 2013; Adedokun et al., 2014; Gilmore, Vieyra, Timmerman, Feldon, \& Maher, 2015; Craney et al., 2011; Fechheimer, Webber, \& Kleiber, 2010), internships (Spooner, Flowers, Lambert, \& Algozzine, 2008; Darling-Hammond, Chung, \& Frelow, 2002; Grasgreen, 2012), servicelearning (Kendrick, 1996; Markus, Howard, \& King, 1993), and student leadership (MultiInstitutional Study of Leadership, 2015; West, 2012).

Coker and Porter (2015) found that multiple experiences involving experiential learning (including study abroad) were associated with more success in job attainment and acceptance into graduate school. In a longitudinal study of over 2,000 students across five forms of experiential learning, Coker, Heiser, Taylor, and Book (2017) showed that the duration of experiences was associated with gains in acquiring a broad general education, writing clearly and effectively, contributing to the welfare of communities, relationships with faculty and administration, desire to attend the same institution, higher order thinking (synthesis and application) in the senior year, and overall educational experience. 
Most previous studies of study abroad duration directly compared shorter programs with longer programs at the conclusion of those experiences, which of course is valuable. However, most did not compare them through the lens of the larger college experience. It stands to reason that substantially less time abroad will lead to less learning while abroad, and so perhaps it should not be surprising that better outcomes could be measured after sixteen weeks compared to three weeks, for example. A tougher yet more practical question is what sort of study abroad experience will lead to the best outcomes for the entire college experience, given that students could do something else productive with the time not spent abroad. The current study addresses this question using the responses of graduating seniors to the National Survey of Student Engagement, examining students who completed three-week and semester-long programs.

The current study also examines whether there are additive benefits of doing a short-term program in addition to another short-term or semester program. Although authors such as Chieffo and Griffiths (2004) have mentioned the importance of this question, we are aware of no other study that attempts to address it.

\section{The National Survey of Student Engagement}

One of the principal tools for demonstrating the connection between student experiences and educational outcomes is the National Survey of Student Engagement (NSSE). Established in 1999 and in use by more than half of all colleges and universities in the United States, the NSSE employs a number of self-reported variables to measure and illustrate effective educational practices. Past studies comparing NSSE results to direct measures of learning have found the NSSE to be a good proxy measure for growth in important educational outcomes (NSSE, 2007; Pascarella, Seifert, \& Blaich, 2010).

The NSSE asks students whether or not they have participated in several forms of experiential learning, including study abroad, but it does not typically ask about specifics within those practices. Thus, pairing NSSE data with other sources of information is necessary for studies comparing types or lengths of programs. To conduct this study, five years of data were used from responses to the NSSE and co-curricular transcripts of graduating seniors at Elon University.

\section{Context for Study}

Elon University is a logical environment to pose research questions related to study abroad and other forms of experiential learning. The school has required experiential learning for more than 20 years and has significant participation by students in several experiential areas. Elon also has participated in the NSSE since 2003 and consistently performed near the top of all institutions, largely due to a rich environment for experiential learning. Students are required to complete an experiential learning requirement as part of the Elon Core Curriculum, choosing from the following: study abroad, undergraduate research, internships, service-learning, or leadership experiences. The vast majority of students far surpass the requirement. At the time of this study, $72 \%$, of graduating students participated in study abroad. This level of student participation provides a large sample size for comparative studies.

Most study abroad experiences at Elon fall into one of two categories. First, short-term courses take place over a three-week term in January. During the study period, the vast majority of 
these involved around twenty days of international travel and a one-credit pre-departure course that took place in the previous semester. Second, semester programs typically involve more than three months either at another institution abroad or at one of three Elon Center programs in London, Costa Rica, or Florence. During the study period, about two-thirds of study abroad experiences were short-term and about a third were semester-long. Short-term experiences typically spent a higher proportion of time traveling from place to place, while semester experiences were more embedded in a location.

\section{Methods}

\section{Data Collection}

Data from five graduating classes of Elon University $(n=4,763)$ were drawn from Elon Experiences Transcripts (EETs) and the National Survey of Student Engagement (NSSE). The EET documents for-credit and not-for-credit experiences at the university in five areas of experiential learning: study abroad, undergraduate research, internships, service, and leadership. The EET is generated and validated by compiling the annual reports from each of the experiential learning offices and by a review of students' academic transcripts. Items from the NSSE were included in the study when they were potentially relevant for study abroad outcomes.

The final data set included students who began college at Elon, graduated within six years, and completed the NSSE $(n=2,058)$. In addition, records were excluded for students who completed the NSSE while studying abroad $(n=18)$ or before studying abroad $(n=15)$, and for students completing summer abroad experiences (because summer experiences were so variable in terms of length and type; $n=115)$. Furthermore, records were only analyzed for students who did not study abroad $(n=515)$, completed one short-term experience $(n=655)$, completed two short-term experiences $(n=146)$, completed one semester experience $(n=389)$, or completed one short-term and one semester study abroad experience $(\mathrm{n}=153)$. Students who completed other combinations, such as, three short-terms, four short-terms, or three short-terms and a semester study abroad experience were excluded. There were a total of $n=52$ students who completed one of these 'other' combinations of study abroad. Overall, the final data set included 1,858 students.

\section{Statistical Analysis}

Responses to the selected NSSE items were summarized based on type of study abroad using means, standard deviations, and counts. The Kruskal-Wallis test was used to identify differences in the population distributions of responses on the items from the NSSE based on type of study abroad experience since the data was heavily skewed. Bonferroni's adjustment method to control for Type I error was used to detect differences in ranks of responses based on each pair of study abroad experiences using simultaneous confidence intervals. The results report use information from the Kruskal-Wallis test and the simultaneous confidence intervals for pairwise differences in ranks to infer differences.

\section{Results}

Participation in Educationally Purposeful Activities During Senior Year

Table 1 shows the relationship between different study abroad experiences and student participation in different educationally purposeful activities during the final year of college. Students responded to the question "In your experience at your institution during the current school year, 
about how often have you done each of the following?" ( $1=$ Never, $2=$ Sometimes, $3=$ Often, $4=$ Very Often) for six items shown in the table.

Table 1. Effects of various study abroad experiences on how students respond to the question, "In your experience at your institution during the current school year, about how often have you done each of the following?" (1=Never, 2=Sometimes, $\mathbf{3}=\mathbf{O f t e n ,} \mathbf{4 = V e r y}$ often). The cells report the mean, standard deviation, and number of responses across five categories of study abroad experiences. * indicates $\mathrm{p}<0.10$; ** indicates $\mathrm{p}<0.05$; and $* * *$ indicates $\mathrm{p}<0.01$. ${ }^{\text {ab }}$ indicate significant pairwise differences in the ranks for each item at the $\alpha=0.10$ significance level.

\begin{tabular}{|c|c|c|c|c|c|c|}
\hline & None & $\begin{array}{l}\text { Winter } \\
\text { Term }\end{array}$ & $\begin{array}{l}2 \text { Winter } \\
\text { Terms }\end{array}$ & Semester & $\begin{array}{l}\text { Sem. + } \\
\text { Winter }\end{array}$ & \\
\hline $\begin{array}{l}\text { Asked questions in class or } \\
\text { contributed to class discussions }\end{array}$ & $\begin{array}{l}3.33^{\mathrm{ab}}(0.78) \\
\mathrm{n}=510\end{array}$ & $\begin{array}{l}3.40(0.79) \\
\mathrm{n}=649\end{array}$ & $\begin{array}{l}3.46(0.71) \\
\mathrm{n}=143\end{array}$ & $\begin{array}{l}3.51^{\mathrm{a}}(0.72) \\
\mathrm{n}=387\end{array}$ & $\begin{array}{l}3.51^{\mathrm{b}}(0.70) \\
\mathrm{n}=153\end{array}$ & $* * *$ \\
\hline $\begin{array}{l}\text { Included diverse perspectives } \\
\text { (different races, religions, } \\
\text { genders, political beliefs, etc.) in } \\
\text { class discussions or writing } \\
\text { assignments }\end{array}$ & $\begin{array}{l}2.84^{\mathrm{a}}(0.89) \\
\mathrm{n}=508\end{array}$ & $\begin{array}{l}2.93(0.82) \\
\mathrm{n}=642\end{array}$ & $\begin{array}{l}2.80(0.88) \\
n=144\end{array}$ & $\begin{array}{l}3.00^{\mathrm{a}}(0.81) \\
\mathrm{n}=386\end{array}$ & $\begin{array}{l}2.98(0.79) \\
\mathrm{n}=151\end{array}$ & $* *$ \\
\hline $\begin{array}{l}\text { Put together ideas or concepts } \\
\text { from different courses when } \\
\text { completing assignments or during } \\
\text { class discussions }\end{array}$ & $\begin{array}{l}3.09^{\mathrm{a}}(0.75) \\
\mathrm{n}=488\end{array}$ & $\begin{array}{l}3.12(0.74) \\
\mathrm{n}=610\end{array}$ & $\begin{array}{l}3.11(0.74) \\
\mathrm{n}=135\end{array}$ & $\begin{array}{l}3.20(0.70) \\
\mathrm{n}=370\end{array}$ & $\begin{array}{l}3.30^{\mathrm{a}}(0.61) \\
\mathrm{n}=145\end{array}$ & $* *$ \\
\hline $\begin{array}{l}\text { Worked with faculty members on } \\
\text { activities other than coursework } \\
\text { (committees, orientation, student } \\
\text { life activities, etc.) }\end{array}$ & $\begin{array}{l}2.32^{\mathrm{a}}(1.01) \\
\mathrm{n}=479\end{array}$ & $\begin{array}{l}2.45(0.95) \\
\mathrm{n}=600\end{array}$ & $\begin{array}{l}2.40(1.01) \\
\mathrm{n}=136\end{array}$ & $\begin{array}{l}2.42(0.91) \\
\mathrm{n}=363\end{array}$ & $\begin{array}{l}2.57^{\mathrm{a}}(0.98) \\
\mathrm{n}=143\end{array}$ & $* *$ \\
\hline $\begin{array}{l}\text { Had serious conversations with } \\
\text { students of a different race or } \\
\text { ethnicity than your own }\end{array}$ & $\begin{array}{l}2.75(0.96) \\
n=479\end{array}$ & $\begin{array}{l}2.61(0.92) \\
n=603\end{array}$ & $\begin{array}{l}2.56(0.89) \\
\mathrm{n}=135\end{array}$ & $\begin{array}{l}2.61(0.91) \\
n=363\end{array}$ & $\begin{array}{l}2.66(0.90) \\
n=143\end{array}$ & $*$ \\
\hline $\begin{array}{l}\text { Had serious conversations with } \\
\text { students who are very different } \\
\text { from you in terms of their } \\
\text { religious beliefs, political } \\
\text { opinions, or personal values }\end{array}$ & $\begin{array}{l}2.94(0.88) \\
\mathrm{n}=480\end{array}$ & $\begin{array}{l}2.88(0.88) \\
\mathrm{n}=604\end{array}$ & $\begin{array}{l}2.87(0.82) \\
n=135\end{array}$ & $\begin{array}{l}2.92(0.85) \\
n=364\end{array}$ & $\begin{array}{l}2.90(0.80) \\
n=144\end{array}$ & \\
\hline
\end{tabular}

Differences in scores based on different levels of study abroad experience were seen in responses to the item "asked questions in class or contributed to class discussions" $\left(\chi^{2}(4)=15.73, p\right.$ $=0.0034)$. Pairwise comparisons indicated that completing a semester experience, or one semester experience and one short-term experience, is associated with significantly greater scores than having completed no study abroad experiences. Differences in scores were also seen in response to "included diverse perspectives in class discussions or writing assignments" $\left(\chi^{2}(4)=11.54, p=\right.$ 0.0211). Pairwise comparisons indicated that completing a semester experience is associated with significantly greater scores than having no study abroad experiences. Differences in scores were seen in responses to two additional items: "put together ideas or concepts from different courses when completing assignments or during class discussions" $\left(\chi^{2}(4)=10.06, p=0.0394\right)$, and "worked with 
faculty members on activities other than coursework" $\left(\chi^{2}(4)=9.66, p=0.0465\right)$. Pairwise comparisons indicated that completing one semester experience plus one short-term experience is associated with significantly greater scores than having no study abroad experiences.

Finally, there was some evidence that "had serious conversations with students of a different race or ethnicity than your own" was rated higher by students who did not study abroad $\left(\chi^{2}(4)=\right.$ $8.44, p=0.0768)$, though no pairwise differences were seen. There were no significant differences in scores based on study abroad experience for the item "had serious conversations with students who are very different from you in terms of their religious beliefs, political opinions, or personal values" $\left(\chi^{2}(4)=2.12, p=0.7132\right)$.

Table 2. Effects of various study abroad experiences on how students respond to the question, "During the current school year, how much has your coursework emphasized the following mental activities?" (1=Very little, 2=Some, 3=Quite a bit, 4=Very much). The cells report the mean, standard deviation, and number of responses across five categories of study abroad experiences. $*$ indicates $\mathrm{p}<0.10 ; * *$ indicates $\mathrm{p}<0.05$; and $* * *$ indicates $\mathrm{p}<0.01$. ${ }^{\text {ab }}$ indicate significant pairwise differences in ranks for each item at the $\alpha=0.10$ significance level.

\begin{tabular}{|c|c|c|c|c|c|c|}
\hline & None & $\begin{array}{l}\text { Winter } \\
\text { Term }\end{array}$ & $\begin{array}{l}2 \text { Winter } \\
\text { Terms }\end{array}$ & Semester & $\begin{array}{l}\text { Sem. }+ \\
\text { Winter }\end{array}$ & \\
\hline $\begin{array}{l}\text { Memorizing facts, ideas, or methods } \\
\text { from your courses and readings so you } \\
\text { can repeat them in pretty much the } \\
\text { same form }\end{array}$ & $\begin{array}{l}2.74^{\mathrm{a}}(0.92) \\
\mathrm{n}=478\end{array}$ & $\begin{array}{l}2.67^{\mathrm{b}}(0.89) \\
\mathrm{n}=595\end{array}$ & $\begin{array}{l}2.72(0.88) \\
n=133\end{array}$ & $\begin{array}{l}2.51^{\mathrm{ab}}(0.92) \\
\mathrm{n}=358\end{array}$ & $\begin{array}{l}2.60(0.81) \\
n=144\end{array}$ & $* * *$ \\
\hline $\begin{array}{l}\text { Analyzing the basic elements of an } \\
\text { idea, experience, or theory, such as } \\
\text { examining a particular case or situation } \\
\text { in depth and considering its } \\
\text { components }\end{array}$ & $\begin{array}{l}3.30^{\mathrm{a}}(0.72) \\
\mathrm{n}=475\end{array}$ & $\begin{array}{l}3.41(0.63) \\
n=594\end{array}$ & $\begin{array}{l}3.53^{\mathrm{a}}(0.64) \\
\mathrm{n}=135\end{array}$ & $\begin{array}{l}3.41(0.62) \\
\mathrm{n}=356\end{array}$ & $\begin{array}{l}3.43(0.63) \\
\mathrm{n}=144\end{array}$ & $* * *$ \\
\hline $\begin{array}{l}\text { Synthesizing and organizing ideas, } \\
\text { information, or experiences into new, } \\
\text { more complex interpretations and } \\
\text { relationships }\end{array}$ & $\begin{array}{l}3.19^{\mathrm{a}}(0.79) \\
\mathrm{n}=473\end{array}$ & $\begin{array}{l}3.26(0.75) \\
n=592\end{array}$ & $\begin{array}{l}3.32(0.74) \\
\mathrm{n}=134\end{array}$ & $\begin{array}{l}3.37^{\mathrm{a}}(0.68) \\
\mathrm{n}=360\end{array}$ & $\begin{array}{l}3.33(0.68) \\
n=142\end{array}$ & $* *$ \\
\hline $\begin{array}{l}\text { Making judgements about the value } \\
\text { of information, arguments, or methods, } \\
\text { such as examining how others } \\
\text { interpreted data and assessing the } \\
\text { soundness of their conclusions }\end{array}$ & $\begin{array}{l}3.09(0.81) \\
\mathrm{n}=475\end{array}$ & $\begin{array}{l}3.13(0.78) \\
n=594\end{array}$ & $\begin{array}{l}3.16(0.78) \\
n=134\end{array}$ & $\begin{array}{l}3.23(0.76) \\
\mathrm{n}=358\end{array}$ & $\begin{array}{l}3.15(0.72) \\
\mathrm{n}=143\end{array}$ & \\
\hline $\begin{array}{l}\text { Applying theories or concepts to } \\
\text { practical problems or in new situations }\end{array}$ & $\begin{array}{l}3.32(0.81) \\
n=477\end{array}$ & $\begin{array}{l}3.41(0.71) \\
n=594\end{array}$ & $\begin{array}{l}3.43(0.70) \\
n=136\end{array}$ & $\begin{array}{l}3.45(0.73) \\
n=361\end{array}$ & $\begin{array}{l}3.37(0.69) \\
n=144\end{array}$ & \\
\hline
\end{tabular}

\section{Nature of Coursework During Senior Year}

Table 2 shows the relationships between study abroad experiences and mental activities emphasized in the senior year. Students responded to the question "During the current year, how much has your coursework emphasized the following mental activities?" (1=Never, 2=Sometimes, 3=Often, 4=Very Often). 
Interestingly, scores related to synthesizing were higher for semester abroad students compared to those with no study abroad $\left(\chi^{2}(4)=11.38, p=0.0226\right)$. Conversely, scores related to memorizing facts were lower for semester abroad students compared to students on short-term programs or with no study abroad $\left(\chi^{2}(4)=14.37, p=0.0062\right)$. In addition, students who studied abroad for two short-terms rated analyzing higher than did students with no study abroad $\left(\chi^{2}(4)=13.98, p=\right.$ 0.0073). Taken altogether, there is some evidence that study abroad may promote higher order thinking in the senior year. There were no significant differences detected in scores based on study abroad experiences for the items on making judgements $\left(\chi^{2}(4)=6.65, p=0.1555\right)$ and applying theories $\left(\chi^{2}(4)=6.78, p=0.1482\right)$.

\section{Multiple Perspectives}

Table 3 shows the relationship between different study abroad experiences and attempts to view things from a different perspective. Students responded to the question "During the current year, about how often have you done each of the following?" ( $1=$ Never, $2=$ Sometimes, $3=$ Often, $4=$ Very Often) for the three items shown in the table.

There was evidence that "tried to better understand someone else's views by imagining how an issue looks from his or her perspective" was rated as occurring more frequently by students who had studied abroad for a semester compared to those who studied abroad for a short-term $\left(\chi^{2}(4)=9.31\right.$, $p=0.0538)$. There were no significant differences in ratings based on study abroad experiences on the items "examined the strengths and weaknesses of your own views on a topic or issue" $\left(\chi^{2}(4)=\right.$ $1.73, p=0.7852)$ or "learned something that changed the way you understand an issue or concept" $\left(\chi^{2}(4)=3.02, p=0.5552\right)$.

Table 3. Effects of various study abroad experiences on how students respond to the question, "During the current school year, about how often have you done each of the following?" (1=Never, 2=Sometimes, 3=Often, 4=Very often). The cells report the mean, standard deviation, and number of responses across five categories of study abroad experiences. $*$ indicates $\mathrm{p}<$ 0.10 ; $* *$ indicates $\mathrm{p}<0.05$; and $* * *$ indicates $\mathrm{p}<0.01$. a indicates significant pairwise differences at the $\alpha=0.10$ significance level.

\begin{tabular}{|c|c|c|c|c|c|}
\hline & None & Winter Term & $\begin{array}{l}2 \text { Winter } \\
\text { Terms }\end{array}$ & Semester & $\begin{array}{l}\text { Sem. + } \\
\text { Winter }\end{array}$ \\
\hline $\begin{array}{l}\text { Examined the strengths and } \\
\text { weaknesses of your own views on a } \\
\text { topic or issue }\end{array}$ & $\begin{array}{l}2.75(0.84) \\
n=466\end{array}$ & $\begin{array}{l}2.73(0.84) \\
n=583\end{array}$ & $\begin{array}{l}2.81(0.84) \\
n=135\end{array}$ & $\begin{array}{l}2.78(0.78) \\
n=353\end{array}$ & $\begin{array}{l}2.76(0.75) \\
n=140\end{array}$ \\
\hline $\begin{array}{l}\text { Tried to better understand someone } \\
\text { else's views by imagining how an } \\
\text { issue looks from his or her } \\
\text { perspective }\end{array}$ & $\begin{array}{l}2.92(0.79) \\
n=467\end{array}$ & $\begin{array}{l}2.82^{\mathrm{a}}(0.79) \\
\mathrm{n}=588\end{array}$ & $\begin{array}{l}2.87(0.82) \\
n=134\end{array}$ & $\begin{array}{l}2.98^{a}(0.75) \\
n=353\end{array}$ & $\begin{array}{l}2.91(0.74) \\
n=140\end{array}$ \\
\hline $\begin{array}{l}\text { Learned something that changed the } \\
\text { way you understand an issue or } \\
\text { concept }\end{array}$ & $\begin{array}{l}3.01(0.76) \\
n=469\end{array}$ & $\begin{array}{l}2.97(0.76) \\
n=589\end{array}$ & $\begin{array}{l}3.02(0.76) \\
n=136\end{array}$ & $\begin{array}{l}3.03(0.75) \\
n=355\end{array}$ & $\begin{array}{l}3.08(0.72) \\
n=144\end{array}$ \\
\hline
\end{tabular}




\section{Relationships}

Table 4 shows the links between different study abroad experiences and student relationships with other people. Students responded to the question "Mark the box that best represents your relationships with people at your institution." ( $1=$ Unfriendly, unsupportive, sense of alienation; $7=$ friendly, supportive, sense of belonging) for three items shown in the table.

Table 4. Effects of various study abroad experiences on how students respond to the question, "Mark the box that best represents your relationships with people at your institution?" (1=Unfriendly, unsupportive, sense of alienation; $7=$ friendly, supportive, sense of belonging). The cells report the mean, standard deviation, and number of responses across five categories of study abroad experiences. * indicates $\mathrm{p}<0.10$; ** indicates $\mathrm{p}<0.05$; and $* * *$ indicates $\mathrm{p}<0.01$. ${ }^{\text {ab }}$ indicate significant pairwise differences at the $\alpha=0.10$ significance level.

\begin{tabular}{llllll}
\hline & None & Winter Term & $\begin{array}{l}\text { 2 Winter } \\
\text { Terms }\end{array}$ & Semester & $\begin{array}{l}\text { Sem. + } \\
\text { Winter }\end{array}$ \\
$\begin{array}{lllll}\text { Relationships with other } \\
\text { students }\end{array}$ & $\begin{array}{l}5.71^{\mathrm{ab}}(1.32) \\
\mathrm{n}=465\end{array}$ & $\begin{array}{l}5.94^{\mathrm{a}}(1.14) \\
\mathrm{n}=584\end{array}$ & $\begin{array}{l}5.94(1.13) \\
\mathrm{n}=135\end{array}$ & $\begin{array}{l}5.88(1.15) \\
\mathrm{n}=350\end{array}$ & $\begin{array}{l}6^{\mathrm{b}}\left(0.15^{\mathrm{b}}(0.99)\right. \\
\mathrm{n}=140\end{array}$ \\
$\begin{array}{l}\text { Relationships with faculty } \\
\text { members }\end{array}$ & $\begin{array}{l}5.92(1.13) \\
\mathrm{n}=464\end{array}$ & $\begin{array}{l}6.03(0.95) \\
\mathrm{n}=584\end{array}$ & $\begin{array}{l}6.01(1.02) \\
\mathrm{n}=133\end{array}$ & $\begin{array}{l}6.06(0.96) \\
\mathrm{n}=350\end{array}$ & $\begin{array}{l}6.06(0.99) \\
\mathrm{n}=141\end{array}$ \\
$\begin{array}{l}\text { Relationships with } \\
\begin{array}{l}\text { administrative personnel and } \\
\text { offices }\end{array}\end{array}$ & $\begin{array}{l}5.00(1.49) \\
\mathrm{n}=465\end{array}$ & $\begin{array}{l}5.06(1.40) \\
\mathrm{n}=585\end{array}$ & $\begin{array}{l}5.16(1.36) \\
\mathrm{n}=134\end{array}$ & $\begin{array}{l}5.14(1.30) \\
\mathrm{n}=350\end{array}$ & $\begin{array}{l}5.11(1.35) \\
\mathrm{n}=141\end{array}$ \\
\hline
\end{tabular}

"Relationships with other students" were rated significantly lower for students who did not study abroad, particularly compared to students on short-term and semester plus short-term programs $\left(\chi^{2}(4)=15.31, p=0.0041\right)$. There was no evidence of a significant difference in ratings based on study abroad experience for "relationships with faculty members" $\left(\chi^{2}(4)=2.74, p=\right.$ $0.6020)$ or "relationships with administrative personnel and offices" $\left(\chi^{2}(4)=1.66, p=0.7987\right)$.

\section{Perceived Learning and Personal Development}

Table 5 shows the relationship between different levels of study abroad experience and students' perceived learning and personal development. Students responded to the question "To what extent has your experience at this institution contributed to your knowledge, skills, and personal development in the following areas?" (1=Very little, 2=Some, 3=Quite a bit, 4=Very much) for 15 items shown in the table.

Semester study abroad experiences were associated with scores that were significantly higher than not studying abroad for three items: acquiring a broad general education $\left(\chi^{2}(4)=21.64, p=\right.$ $0.0002)$, thinking critically and analytically $\left(\chi^{2}(4)=9.81, p=0.0437\right)$, and working effectively with others $\left(\chi^{2}(4)=11.61, p=0.0205\right)$. On the "acquiring a broad general education" item, students with a semester and short-term study abroad also scored significantly higher than students with no study abroad, but the difference was not statistically significant between the semester students and the students who completed one semester and one short-term study abroad. Study abroad also appears to be associated with writing clearly and effectively $\left(\chi^{2}(4)=8.83, p=0.0655\right)$ and understanding yourself $\left(\chi^{2}(4)=7.97, p=0.0928\right)$, though no pairwise differences were detected between specific categories. There were no significant differences detected in scores based on study abroad experiences for the remaining ten items. 
Table 5. Effects of various study abroad experiences on how students respond to the question, "To what extent has your experience at this institution contributed to your knowledge, skills, and personal development in the following areas?" (1=Very little, $2=$ =Some, $3=$ Quite a bit, 4=Very much). The cells report the mean, standard deviation, and number of responses across five categories of study abroad experiences. $*$ indicates $\mathrm{p}<0.10$; $* *$ indicates $\mathrm{p}<0.05$; and $* * *$ indicates $\mathrm{p}<0.01$. ab indicate significant pairwise differences at the $\alpha=0.10$ significance level.

\begin{tabular}{|c|c|c|c|c|c|c|}
\hline & None & Winter Term & $\begin{array}{l}2 \text { Winter } \\
\text { Terms }\end{array}$ & Semester & $\begin{array}{l}\text { Sem. + } \\
\text { Winter }\end{array}$ & \\
\hline $\begin{array}{l}\text { Acquiring a broad general } \\
\text { education }\end{array}$ & $\begin{array}{l}3.45^{\mathrm{ab}}(0.71) \\
\mathrm{n}=450\end{array}$ & $\begin{array}{l}3.55(0.62) \\
\mathrm{n}=573\end{array}$ & $\begin{array}{l}3.60(0.66) \\
n=132\end{array}$ & $\begin{array}{l}3.63^{\mathrm{a}}(0.60) \\
\mathrm{n}=341\end{array}$ & $\begin{array}{l}3.69^{\mathrm{b}}(0.55) \\
\mathrm{n}=138\end{array}$ & $* * *$ \\
\hline $\begin{array}{l}\text { Acquiring job or work- } \\
\text { related knowledge and skills }\end{array}$ & $\begin{array}{l}3.23(0.85) \\
\mathrm{n}=449\end{array}$ & $\begin{array}{l}3.21(0.87) \\
\mathrm{n}=571\end{array}$ & $\begin{array}{l}3.17(0.81) \\
\mathrm{n}=131\end{array}$ & $\begin{array}{l}3.32(0.81) \\
\mathrm{n}=341\end{array}$ & $\begin{array}{l}3.27(0.84) \\
n=139\end{array}$ & \\
\hline $\begin{array}{l}\text { Writing clearly and } \\
\text { effectively }\end{array}$ & $\begin{array}{l}3.29(0.77) \\
n=446\end{array}$ & $\begin{array}{l}3.38(0.74) \\
\mathrm{n}=572\end{array}$ & $\begin{array}{l}3.36(0.74) \\
n=132\end{array}$ & $\begin{array}{l}3.43(0.70) \\
n=340\end{array}$ & $\begin{array}{l}3.47(0.63) \\
n=139\end{array}$ & * \\
\hline $\begin{array}{l}\text { Speaking clearly and } \\
\text { effectively }\end{array}$ & $\begin{array}{l}3.27(0.79) \\
\mathrm{n}=448\end{array}$ & $\begin{array}{l}3.30(0.81) \\
\mathrm{n}=574\end{array}$ & $\begin{array}{l}3.26(0.76) \\
n=131\end{array}$ & $\begin{array}{l}3.35(0.77) \\
\mathrm{n}=338\end{array}$ & $\begin{array}{l}3.28(0.72) \\
n=139\end{array}$ & \\
\hline $\begin{array}{l}\text { Thinking critically and } \\
\text { analytically }\end{array}$ & $\begin{array}{l}3.46^{a}(0.70) \\
n=446\end{array}$ & $\begin{array}{l}3.53(0.65) \\
n=570\end{array}$ & $\begin{array}{l}3.53(0.66) \\
n=132\end{array}$ & $\begin{array}{l}3.60^{\mathrm{a}}(0.61) \\
\mathrm{n}=341\end{array}$ & $\begin{array}{l}3.53(0.65) \\
n=136\end{array}$ & $* *$ \\
\hline $\begin{array}{l}\text { Analyzing quantitative } \\
\text { problems }\end{array}$ & $\begin{array}{l}3.02(0.89) \\
n=449\end{array}$ & $\begin{array}{l}3.08(0.87) \\
\mathrm{n}=566\end{array}$ & $\begin{array}{l}3.17(0.81) \\
\mathrm{n}=131\end{array}$ & $\begin{array}{l}2.96(0.89) \\
\mathrm{n}=340\end{array}$ & $\begin{array}{l}2.94(0.93) \\
n=138\end{array}$ & \\
\hline $\begin{array}{l}\text { Using computing and } \\
\text { information technology }\end{array}$ & $\begin{array}{l}3.20(0.84) \\
n=448\end{array}$ & $\begin{array}{l}3.18(0.83) \\
\mathrm{n}=573\end{array}$ & $\begin{array}{l}3.25(0.76) \\
\mathrm{n}=130\end{array}$ & $\begin{array}{l}3.15(0.84) \\
n=342\end{array}$ & $\begin{array}{l}3.06(0.87) \\
n=139\end{array}$ & \\
\hline $\begin{array}{l}\text { Working effectively with } \\
\text { others }\end{array}$ & $\begin{array}{l}3.46^{\mathrm{a}}(0.73) \\
\mathrm{n}=448\end{array}$ & $\begin{array}{l}3.57(0.63) \\
\mathrm{n}=572\end{array}$ & $\begin{array}{l}3.51(0.61) \\
n=132\end{array}$ & $\begin{array}{l}3.61^{\mathrm{a}}(0.64) \\
\mathrm{n}=342\end{array}$ & $\begin{array}{l}3.57(0.65) \\
n=138\end{array}$ & $* *$ \\
\hline $\begin{array}{l}\text { Voting in local, state, or } \\
\text { national elections }\end{array}$ & $\begin{array}{l}2.36(1.03) \\
n=445\end{array}$ & $\begin{array}{l}2.38(1.03) \\
\mathrm{n}=569\end{array}$ & $\begin{array}{l}2.36(1.06) \\
n=130\end{array}$ & $\begin{array}{l}2.41(1.01) \\
\mathrm{n}=335\end{array}$ & $\begin{array}{l}2.36(0.91) \\
n=138\end{array}$ & \\
\hline $\begin{array}{l}\text { Learning effectively on your } \\
\text { own }\end{array}$ & $\begin{array}{l}3.23(0.78) \\
n=445\end{array}$ & $\begin{array}{l}3.21(0.76) \\
n=569\end{array}$ & $\begin{array}{l}3.38(0.71) \\
\mathrm{n}=129\end{array}$ & $\begin{array}{l}3.27(0.74) \\
n=336\end{array}$ & $\begin{array}{l}3.20(0.75) \\
n=137\end{array}$ & \\
\hline Understanding yourself & $\begin{array}{l}3.09(0.91) \\
\mathrm{n}=445\end{array}$ & $\begin{array}{l}3.15(0.83) \\
\mathrm{n}=564\end{array}$ & $\begin{array}{l}3.30(0.75) \\
\mathrm{n}=129\end{array}$ & $\begin{array}{l}3.23(0.83) \\
\mathrm{n}=335\end{array}$ & $\begin{array}{l}3.24(0.80) \\
n=137\end{array}$ & $*$ \\
\hline $\begin{array}{l}\text { Understanding people of } \\
\text { other racial and ethnic } \\
\text { backgrounds }\end{array}$ & $\begin{array}{l}2.60(1.00) \\
n=442\end{array}$ & $\begin{array}{l}2.58(0.93) \\
\mathrm{n}=567\end{array}$ & $\begin{array}{l}2.48(0.96) \\
n=130\end{array}$ & $\begin{array}{l}2.56(0.92) \\
\mathrm{n}=328\end{array}$ & $\begin{array}{l}2.49(0.98) \\
n=136\end{array}$ & \\
\hline $\begin{array}{l}\text { Solving complex real-world } \\
\text { problems }\end{array}$ & $\begin{array}{l}2.93(0.93) \\
n=443\end{array}$ & $\begin{array}{l}2.96(0.84) \\
\mathrm{n}=567\end{array}$ & $\begin{array}{l}2.98(0.90) \\
\mathrm{n}=129\end{array}$ & $\begin{array}{l}3.06(0.81) \\
n=334\end{array}$ & $\begin{array}{l}2.94(0.86) \\
n=136\end{array}$ & \\
\hline $\begin{array}{l}\text { Developing a personal code } \\
\text { of ethics }\end{array}$ & $\begin{array}{l}2.99(0.94) \\
n=443\end{array}$ & $\begin{array}{l}3.00(0.88) \\
\mathrm{n}=566\end{array}$ & $\begin{array}{l}3.09(0.81) \\
\mathrm{n}=129\end{array}$ & $\begin{array}{l}3.09(0.86) \\
\mathrm{n}=335\end{array}$ & $\begin{array}{l}2.95(0.85) \\
n=138\end{array}$ & \\
\hline $\begin{array}{l}\text { Contributing to the welfare } \\
\text { of your community }\end{array}$ & $\begin{array}{l}2.89(0.94) \\
\mathrm{n}=444\end{array}$ & $\begin{array}{l}2.93(0.90) \\
\mathrm{n}=566\end{array}$ & $\begin{array}{l}2.92(0.89) \\
\mathrm{n}=130\end{array}$ & $\begin{array}{l}3.02(0.86) \\
n=335\end{array}$ & $\begin{array}{l}3.03(0.89) \\
n=138\end{array}$ & \\
\hline
\end{tabular}

\section{Overall College Experience}

Table 6 shows the relationship between study abroad experiences and students' overall college experience. Differences in scores based on study abroad experience were seen in how students evaluated their entire educational experience at the institution $\left(\chi^{2}(4)=19.27, p=0.0007\right)$ and in whether students would go to the same institution if they could start over again $\left(\chi^{2}(4)=16.97, p=\right.$ 0.0020). In both cases, pairwise comparisons indicated that students having experienced either shortterm or semester study abroad rated the items higher than students not studying abroad. 
No significant differences in scores based on study abroad experience were seen in how students evaluated the quality of the academic advising $\left(\chi^{2}(4)=2.37, p=0.6688\right)$.

Table 6. Effects of various study abroad experiences on how students respond to various questions from the NSSE. The cells report the mean, standard deviation, and number of responses across five categories of study abroad experiences. * indicates $\mathrm{p}<0.10$; ** indicates $\mathrm{p}<0.05$; and $* * *$ indicates $\mathrm{p}<0.01$. ab indicate significant pairwise differences at the $\alpha=0.10$ significance level.

\begin{tabular}{|c|c|c|c|c|c|c|}
\hline & None & $\begin{array}{l}\text { Winter } \\
\text { Term }\end{array}$ & $\begin{array}{l}2 \text { Winter } \\
\text { Terms }\end{array}$ & Semester & $\begin{array}{l}\text { Sem. + } \\
\text { Winter }\end{array}$ & \\
\hline $\begin{array}{l}\text { Overall, how would you evaluate the } \\
\text { quality of academic advising you have } \\
\text { received at your institution? }(1=\text { Poor, } \\
\text { 2=Fair, } 3=\text { Good, } 4=\text { Excellent })(n=1630)\end{array}$ & $\begin{array}{l}3.27(0.82) \\
\mathrm{n}=447\end{array}$ & $\begin{array}{l}3.23(0.80) \\
n=571\end{array}$ & $\begin{array}{l}3.24(0.78) \\
n=132\end{array}$ & $\begin{array}{l}3.31(0.74) \\
n=341\end{array}$ & $\begin{array}{l}3.27(0.83) \\
\mathrm{n}=139\end{array}$ & \\
\hline $\begin{array}{l}\text { How would you evaluate your entire } \\
\text { educational experience at this } \\
\text { institution? }(1=\text { Poor, } 2=\text { =air, } 3=\text { Good, } \\
4=\text { Excellent })(n=1628)\end{array}$ & $\begin{array}{l}3.53^{\text {ab }}(0.66) \\
n=446\end{array}$ & $\begin{array}{l}3.65^{a}(0.56) \\
n=570\end{array}$ & $\begin{array}{l}3.69(0.51) \\
n=132\end{array}$ & $\begin{array}{l}3.71^{\mathrm{b}}(0.53) \\
\mathrm{n}=341\end{array}$ & $\begin{array}{l}3.67(0.53) \\
n=139\end{array}$ & $* * *$ \\
\hline $\begin{array}{l}\text { If you could start over again, would you } \\
\text { go to the same institution you are now } \\
\text { attending? ( } 1=\text { Definitely no, } \\
\text { 2=Probably no, } 3=\text { Probably yes, } \\
\text { 4=Definitely yes) }(n=1631)\end{array}$ & $\begin{array}{l}3.31^{\mathrm{ab}}(0.83) \\
\mathrm{n}=447\end{array}$ & $\begin{array}{l}3.49^{\mathrm{a}}(0.74) \\
\mathrm{n}=571\end{array}$ & $\begin{array}{l}3.45(0.74) \\
\mathrm{n}=132\end{array}$ & $\begin{array}{l}3.49^{\mathrm{b}}(0.76) \\
\mathrm{n}=342\end{array}$ & $\begin{array}{l}3.42(0.77) \\
\mathrm{n}=139\end{array}$ & $* * *$ \\
\hline
\end{tabular}

\section{Discussion}

\section{Impacts of Program Duration on Outcomes}

This five-year study of graduating seniors at Elon University $(n=1,858)$ compared student outcomes measured at the end of their college experience by the National Survey of Student Engagement across five study abroad groups: no study abroad, semester, short-term (three-week), two short-terms, and semester plus short-term. Overall, both short-term and semester programs were positively associated with how students rate their overall educational experience and whether they would attend the same institution again. Of course, previous studies show that both shortterm and semester programs lead to positive outcomes (Chieffo and Griffiths, 2004; Dwyer, 2004; Gaia, 2015). The current study supports and adds to those findings by showing that the positive outcomes also lead to higher ratings of the overall college experience.

However, only students who participated in semester programs reported better outcomes in numerous categories: contributing to class discussion, including diverse perspectives in discussions and assignments, synthesis of ideas, less rote memorization of course material, empathy, acquiring a broad general education, critical thinking, and working effectively with others. These findings are supported by a previous study showing that depth (amount of time commitment) is associated with better outcomes across several forms of experiential learning (Coker et al., 2017). Likewise, other studies suggest that longer study abroad duration has more benefits in developing intercultural sensitivity, global perspective, linguistic ability, lifelong friendships with host-country nationals, and 
many other outcomes (Dwyer, 2004; Ingraham \& Peterson, 2004; Kehl \& Morris, 2008; MedinaLópez-Portillo, 2004; Zorn, 1996).

Conceptual models for experiential learning suggest a process that is affected by the duration of the experience, though the specifics are often ambiguous. For example, in Kolb's classic experiential learning theory, the cycling between concrete experience, reflective observation, abstract conceptualization, and active experimentation implicitly suggests a time-sensitive process (Kolb, 1984). A more modern model, Co-Constructed Developmental Teaching Theory (CDTT), is more explicit. It suggests that experiential learning takes place through iterative learning cycles that increase in time and complexity with more and more advanced learning (Schenck \& Cruickshank, 2015). The results of the current study support the notion of additive experiential learning over time through longer program duration. As Kuh (2008) said, among the "key elements" of highimpact educational practices is a "significant investment of time and effort by students over an extended period of time" (p. 9).

A primary reason for the existence of short-term study abroad continues to be increasing access for students that would not or could not study abroad otherwise (Coker \& Porter, 2016). Our data suggest that this is entirely appropriate, since short-term programs do lead to better outcomes than not studying abroad. However, short-term programs do not appear to be equivalent to semester programs - a broader array of positive outcomes are associated with semester programs. Thus, a reasonable institutional approach is to offer both, prioritize semester programs, and encourage students to do the longest program that they are able and willing to do. This seems somewhat different from the decades-long trend that has led over $60 \%$ of study abroad experiences to be one to eight weeks in duration (Institute of International Education, 2015).

\section{Effects of an Additional Short-term Experience}

There is very little known about the impacts of having a short-term study abroad experience in addition to another study abroad experience. Given that exposing students to new, unfamiliar environments has potential benefits (Ewert \& Yoshino, 2011; Mackenzie, Son, \& Hollenhorst, 2014), it seems plausible that a second experience at a different location could lead to better outcomes. Nevertheless, this study showed no clear benefits based on NSSE data.

First, there was no convincing evidence that having two short-term experiences led to better outcomes than having just one short-term experience. There were no significant differences when directly comparing the two groups. There was one NSSE item that students with two shortterm experiences rated higher compared to students with no study abroad, while students with one short-term experience did not rate the item higher compared to those not studying abroad ("analyzing the basic elements of an idea, experience, or theory, such as examining a particular case or situation in depth and considering its components" (Table 2). Since there were no such other differences across higher-order thinking items across the study, it may be inconsequential.

Second, there was little evidence that better outcomes resulted from a short-term experience done in addition to a semester experience. Again, there were no differences in direct comparisons between students with one experience (semester) and two experiences (semester plus short-term). There were three NSSE items that students with two experiences rated higher compared to students who did not study abroad, while students with one semester experience did not rate them higher 
compared to those not studying abroad ("put together ideas or concepts from different courses when completing assignments or during class discussions," "worked with faculty members on activities other than coursework," and "relationships with other students"). On the other hand, students with only a semester experience rated numerous items higher compared to students who did not study abroad while no such differences emerged for those with two experiences (though this could be an artifact of sample size differences). Taken altogether, if there is a benefit to the second experience, it would appear to be small and possibly inconsequential as measured by the NSSE.

Overall, the data suggest that a student who has experienced a short-term program abroad would likely find additional benefits by then taking a semester program, but a student who has already studied abroad may find far less benefit in experiencing an additional short-term program. This finding supports previous studies suggesting that short-term study abroad is valuable as a developmental step for first- and second-year students, after which they might study abroad for a semester (Coker \& Porter, 2015; Gaia, 2015; Gorka \& Niesenbaum, 2001). It is also possible that short-term programs would be more valuable as a second experience if they were more scaffolded and more challenging than a student's first program.

\section{Study Limitations and Future Work}

The limitations of this study are fourfold. First, although the NSSE is a widely used instrument with verified correlation to direct measures of learning (Pascarella, Seifert, \& Blaich, 2010), it is still an indirect measure. Second, study abroad program characteristics may vary depending on context. Although it seems likely that the findings here will be transferable to many other institutions, differences in student demographics, experiential programs, and curricular requirements may lead to different perspectives. Third, the sample sizes were different across the five study groups. Thus, it is possible that some differences between groups were not detected (while others were) because the probability of detecting a difference decreases with lower sample size. In particular, the two shortterm experience and the semester plus short-term groups had much smaller sample sizes than the other three groups, which could have impacted the ability to detect when those experiences yielded significantly different results. Finally, study abroad experiences are self-selected. That is, students select the length of the experience and the factors that influence those decisions were not investigated or controlled for. For example, it could be that some majors have greater limitations in which experiences fit in with degree requirements, socio-economic factors could impact the length of experiences selected, and personal student characteristics could impact the choice of experiences. These factors could have an impact on the length of experience chosen by students and the impact of those experiences on the student as expressed by items from the NSSE.

Future studies on the impacts of study abroad duration and program type will be very valuable for improving student outcomes. For example, it would be useful to verify (or contradict) the findings here by asking similar questions at other institutional types and across different student demographics. It will also be important to do similar studies using more direct measures of assessing student learning.

\section{Acknowledgements}

Thanks are extended to Morgan Seijo-Vilá for administrative support and Sophia Clotho for her guidance. 


\section{References}

Adedokun, O. A., Parker, L. C., Childress, A., Burgess, W., Adams, R., Agnew, C. R., Leary, J., Knapp, D., Shields, C., Lelievre, S., \& Teegarden, D. (2014). Effect of time on perceived gains from an undergraduate research program. Cell Biology Education, 13(1), 139-148.

Chieffo, L., \& Griffiths, L. (2004). Large-scale assessment of student attitudes after a short-term study abroad program. Journal of Study Abroad, 10, 165-177.

Coker, J. S., \& Porter, D. J. (2015). Maximizing experiential learning for student success. Change: The Magazine of Higher Learning, 47(1), 66-72.

Coker, J. S., \& Porter, D. J. (2016). Student motivations and perception across and within five forms of experiential learning. Journal of General Education, 65(2), 138-156.

Coker, J. S., Heiser, E., Taylor, L., \& Book, C. (2017). Impacts of experiential learning depth and breadth on student outcomes. Journal of Experiential Education, 40(1), 5-23.

Craney, C., McKay, T., Mazzeo, A., Morris, J., Prigodich, C., \& de Groot, R. (2011). Cross-discipline perceptions of the undergraduate research experience. Journal of Higher Education, 82(1), 92-113.

Darling-Hammond, L., Chung, R., \& Frelow, F. (2002). Variation in teacher preparation - How well do different pathways prepare teachers to teach? Journal of Teacher Education, 53(4), 286-302.

Dwyer, M. M. (2004). More is better: The impact of study abroad program duration. Frontiers: The Interdisciplinary Journal of Study Abroad, 10, 151-164.

Engle, L., \& Engle, J. (2003). Study abroad levels: Toward a classification of program types. Frontiers: The Interdisciplinary Journal of Study Abroad, 9(1), 1-20.

Ewert, A., \& Yoshino, A. (2011). The influence of short-term adventure-based experiences on levels of resilience. Journal of Adventure Education and Outdoor Learning, 11, 35-50.

Fechheimer, M., Webber, K., \& Kleiber, P. B. (2010). How well do undergraduate research programs promote engagement and success of students? CBE Life Science Education, 10(2), 156-163.

Gaia, A. C. (2015). Short-term faculty-led study abroad programs enhance cultural exchange and selfawareness. International Education Journal: Comparative Perspectives, 14(1), 21-31.

Gilmore, J., Vieyra, M., Timmerman, B., Feldon, D., \& Maher, M. (2015). The relationship between undergraduate research participation and subsequent research performance of early career STEM graduate students. Journal of Higher Education, 86(6), 834-863.

Gorka, B., \& Niesenbaum, R. (2001). Beyond the language requirement: Interdisciplinary short-term study-abroad. Hispania, 84(1), 100-109.

Grasgreen, A. (2012). Résumé-builder or rip-off? Insider Higher Ed. Retrieved from www.insidehighered.com/news/2012/02/03/growth-short-term-internships-over-academic-breaks.

Ingraham, E. C., \& Peterson, D. L. (2004, Fall). Assessing the impact of study abroad on student learning at Michigan State University. Frontiers: The Interdisciplinary Journal of Study Abroad, 10, 83-100.

Institute of International Education (IIE). (2015). Open Doors Report on International Educational Exchange. Retrieved from www.iie.org/opendoors

Kehl, K., \& Morris, J. (2008). Differences in global-mindedness between short-term and semester-long study abroad participants at selected private universities. Frontiers: The Interdisciplinary Journal of Study Abroad, 15, 67-79.

Kendrick, J. (1996). Outcomes of service-learning in an introduction to sociology course. Michigan Journal of Community Service Learning, 3, 72-81.

Kolb, D. (1984). Experiential learning: Experience as the source of learning and development. Englewood Cliffs, NJ: Prentice Hall.

Kuh, G. D. (2008). High-impact educational practices: What they are, who has access to them, and why they matter. Washington, DC: Association of American Colleges and Universities.

Mackenzie, S. H., Son, J. S., \& Hollenhorst, S. (2014). Unifying psychology and experiential education: Toward an integrated understanding of why it works. Journal of Experiential Education, 37(1), 7588. 
Markus, G., Howard, J., \& King, D. (1993). Integrating community service and classroom instruction enhances learning: Results from an experiment. Education Evaluation \& Policy Analysis, 15, 41019.

Medina-López-Portillo, A. (2004). Intercultural learning assessment: The link between program duration and the development of intercultural sensitivity. Frontiers: The Interdisciplinary Journal of Study Abroad, 10, 179-200.

Multi-Institutional Study of Leadership (MSL). (2015). 2015 Multi-Institutional Study of Leadership. Retrieved from www.leadershipstudy.net

National Survey of Student Engagement (NSSE). (2007). Experiences That Matter: Enhancing Student Learning and Success, NSEE 2007 Annual Report. Indiana University Bloomington: Center for Postsecondary Research School of Education.

Paige, R. M., Fry, G. W., Stallman, E., Josic, J., \& Jon, J. (2009, February). Study abroad for global engagement: Results that inform research and policy agendas. Paper presented at the Forum on Education Abroad Conference, Portland, OR.

Pascarella, E. T., Seifert, T. A., \& Blaich, C. (2010). How effective are the NSSE benchmarks in predicting important educational outcomes? Change, 42(1), 16-22.

Russell, S. H., Hancock, M. P., \& McCullough, J. (2007). Benefits of undergraduate research experiences. Science, 316, 548-549.

Schenck, J., \& Cruickshank, J. (2015). Evolving Kolb: Experiential education in the age of neuroscience. Journal of Experiential Education, 38(1), 73-95.

Spooner, M., Flowers, C., Lambert, R., \& Algozzine, B. (2008). Is more really better? Examining perceived benefits of an extended student teaching experience. Clearing House: A Journal of Educational Strategies, Issues and Ideas, 81(6), 263-270.

Strange, H., \& Gibson, H. J. (2017). An investigation of experiential and transformative learning in study abroad programs. Frontiers: The Interdisciplinary Journal of Study Abroad, 29, 85-100.

Trooboff, S., Vande Berg, M., \& Rayman, J. (2008). Employer attitudes toward study abroad. Frontiers: The Interdisciplinary Journal of Study Abroad, 15, 17-33.

West, C. (2012). Teaching leadership to undergraduates: Lessons from U.S. military colleges. Journal of College Teaching and Learning, 9(2), 135-146.

Woolf, M. (2007). Impossible things before breakfast: Myths in education abroad. Journal of Studies in International Education, 11, 496-509.

Zorn, C. R. (1996). The long-term impact on nursing students of participating in international education. Journal of Professional Nursing, 12(2), 106-110.

Zydney, A. L., Bennett, J. S., Shahid, A., \& Bauer, K. W. (2013). Impact of undergraduate research experience in engineering. Journal for Engineering Education, 91(2), 151-157. 